\title{
KINERJA KOMISI PEMILIHAN UMUM DAERAH KABUPATEN LUWU UTARA DALAM PEMUTAKHIRAN DATA PEMILIH PADA PEMILIHAN GUBERNUR DAN WAKIL GUBERNUR SULAWESI SELATAN TAHUN 2013
}

\author{
Suparto $^{1}$, Muhammadiah ${ }^{2}$, Syamsir Rahim $^{2}$ \\ ${ }^{1}$ Program Studi Ilmu Pemerintahan Fakultas Ilmu Sosial Dan Ilmu Politik \\ ${ }^{2}$ Program Studi Ilmu Administrasi Negara Fakultas Ilmu Sosial Dan Ilmu Politik \\ Universitas Muhammadiyah Makassar \\ Jl. Sultan Alaudin No. 259 Makassar 90221 Tlp. 0411-866972 ext. 107. Fax. 0411-865588
}

\section{ABSTRACT}

This study aimed at describing the performance of the electoral commission in the North Luwu regency in updating the voters data on the election of Governor and Governor Deputy in 2013, and describing the supporting and obstacles factors of the implementation of the data updating for determining the voters. The research methods used by the author in this study was descriptive-qualitative by using two kinds of data, namely primary and secondary data. The data was analyzed descriptive qualitatively by analyzing all the data collected by the writer, then be displayed in sentences based on the interviews results from the informants who had been determined in advance. The findings showed performance of Electoral Commission of North Luwu regency in the context of updating voters data in the election of South Sulawesi Governor and Governor Deputy in 2013 had been running well but not fully effective. This is proved by many of northern Luwu communities should be registered as voters at the election, but did not get summons for the election, in contrary the number of summonses were realeased for the people whom their presence were not known by the local society, so that the summonses were useless. Moreover, human resources, Loyalty of PPDP members and staff, and cooperation were the supporting factors while the obstacles were the Data of Potential Population of Voters in Election, Lack of Public Participation, Budget, and the total area.

Keywords: performance, electoral commission, data updating

\section{ABSTRAK}

Penelitian ini bertujuan untuk menggambarkan kinerja komisi pemilihan umum kabupaten luwu utara dalam pemutakhiran data pemilih pada pemilihan gubernur dan wakil gubernur tahun 2013, serta menggambarkan faktor yang mendukung dan menghambat dari pelaksanaan pemutakhiran untuk ditetapkannya sebagai pemilih. Metode penelitian yang digunakan penulis dalam penelitian ini adalah deskriftif-kualitatif dengan menggunakan dua macam data yaitu data primer dan data sekunder.Data tersebut kemudian dianalisis secara deskriptif kualitatif yaitu menganalisis semua data yang berhasil dikumpulkan penulis dan selanjutnya ditampilkan dalam bentuk kalimat sesuai dengan hasil wawancara dari beberapa informan yang sebelumya telah ditentukan. Hasil penelitian menunjukkan Kinerja Komisi Pemilihan Umum Kabupaten Luwu Utara dalam konteks pemutakhiran data pemilih pada pemilihan Gubernur dan Wakil Gubernur Sulawesi Selatan tahun 2013 telah berjalan dengan baik namun sepenuhnya belum efektif. Hal ini dibuktikan dengan banyaknya masyarakat luwu utara yang seharusnya terdaftar sebagai pemilih pada pemilihan, tidak mendapat surat panggilan untuk melakukan pemilihan, dan sebaliknya banyaknya surat panggilan yang ditujukan pada orang-orang yang keberadaannya dalam suatu daerah tidak diketahui oleh masyrakat setempat, sehingga surat panggilan tersebut tinggalah menumpuk dan tak dipergunakan. Sumber daya manusia (SDM), Loyalitas anggota PPDP dan staf serta Kerjasama selaku factor pendukung dan adapun sebagai Faktor Penghambat yaitu Data Penduduk Potensial Pemilih Pemilu (DP4), Kurangnya Partisipasi Masyarakat, Anggaran, dan Luas wilayah.

Kata kunci: kinerja, KPUD, pemutakhiran data 


\section{A. PENDAHULUAN}

Sejak tanggal 1 juli 2005, Indonesia untuk pertama kalinya menyelenggarakan pemilihan umum kepala daerah atau populer dengan istilah pemilukada, baik untuk memilih pasangan Gubernur dan Wakil Gubernur, Bupati dan Wakil Bupati, serta Walikota dan Wakil Walikota. Seluruh provinsi, kabupaten dan kotamadya. Pemilihan kepala daerah dan wakil kepala daerah dilaksanakan berdasarkan Undang-undang Nomor 32 Tahun 2004 tentang Pemerintah Daerah.

Menurut Undang-undang Nomor 22 Tahun 2007 pada pasal 1 butir 4 dikatakan bahwa yang dimaksud dengan pemilihan umum Kepala daerah dan Wakil kepala daerah adalah Pemilihan umum untuk memilih Kepala Daearah dan Wakil Kepala Daerah secara langsung dalam Negara Kesatuan Republik Indonesia berdasarkan Pancasila dan Undangundang Dasar Negara Republik Indonesia Tahun 1945 (Sarundajang, 2012: 2).

Dalam rangka peningkatan kualitas penyelenggaraan pemilihan umum, Undangundang Nomor 22 Tahun 2007 diganti dengan Undang-undang Republik Indonesia Nomor 15 Tahun 2011 tentang Penyelenggara Pemilihan Umum. Sesuai dengan Undang-undang Republik Indonesia Nomor 15 Tahun 2011 tentang penyelenggara Pemilihan Umum, yang di maksud dengan Pemilihan Umum, selanjutnya disingkat Pemilu adalah Sarana pelaksanaan kedaulatan rakyat yang diselenggarakan secara langsung, umum, bebas, rahasia, jujur, dan adil dalam Negara Kesatuan Republik Indonesia berdasarkan Pancasila dan Undangundang Dasar Negara Republik Indonesia Tahun 1945. Pemilihan Gubernur, Bupati, dan Walikota adalah pemilihan untuk memilih gubernur, bupati, dan walikota secara demokratis dalam Negara Kesatuan Republik Indonesia berdasarkan Pancasila dan Undang-undang Dasar Republik Indonesia Tahun 1945.

Dalam menjalankan tugasnya, KPU di bantu oleh Sekretariat Jenderal, KPU Provinsi dan KPU Kabupaten/Kota masing-masing dibantu oleh Sekretariat. Jumlah anggota KPU sebanyak 7 (tujuh) orang, KPU Provinsi sebanyak 5 (lima) orang dan KPU Kabupaten/
Kota sebanyak 5 (lima) orang. Keanggotaan KPU, KPU Provinsi, dan KPU Kabupaten/Kota terdiri atas seorang ketua merangkap anggota dan anggota. Setiap anggota KPU, KPU Provinsi dan KPU Kabupaten/Kota mempunyai hak suara yang sama. Komposisi keanggotaan KPU, KPU Provinsi dan KPU Kabupaten/Kota memperhatikan keterwakilan perempuan sekurangkurangnya 30\% (tiga puluh persen). Masa keanggotaan KPU, KPU Provinsi dan KPU Kabupaten/Kota 5 (lima) tahun terhitung sejak pengucapan sumpah/janji. (Hadi, 2012: 91).

Provinsi Sulawesi selatan, dalam hal ini akan melaksanakan penyelenggaraan pemilukada, yakni pemilihan Gubernur dan Wakil gubernur. Dalam penyelenggaraan ini, KPU memiliki peranan penting demi terselenggaranya pemilihanKPU menjalankan tugasnya secara berkesinambungan dan dalam menyelenggarakan pemilu, KPU bebas dari pihak mana pun berkaitan dengan pelaksanaan tugas dan wewenangnya.

Merujuk pada hal demikian, kinerja KPU yang akan dikaji lebih dalam yaitu kinerja KPUD Kabupaten Luwu Utara dalam pemutakhiran data pemilih. Kinerja (performance) yang dimaksud yaitu tentang bagaimana proses kerja berlangsung. Kinerja adalah tentang melakukan pekerjaan dan hasil yang di capai dari pekerjaan tersebut (Armstrong dan Baron, 1998:15).

KPU, dalam penyelenggaraan pemilukada (Gubernur dan Wakil Gubernur) diharapkan mampu bekerja secara profesional dengan memperhatikan tugas dan wewenangnya sebagaimana Undang-undang Republik Indonesia Nomor 15 Tahun 2011 tentang Penyelenggara Pemilihan Umum. Baik KPU Provinsi maupun KPU Kabupaten/Kota. Terkhusus KPU Daerah Kabupaten Luwu Utara tentang bagaimana kinerja dari KPU tersebut dalam pemutakhiran data pemilih pada pemilihan Gubernur dan Wakil Gubernur Sulawesi Selatan.

Pada pemilihan Gubernur Sulawesi Selatan, KPU Daerah Luwu Utara menemukan adanya data pemilih ganda sebesar 12.072 jiwa dari total pemilih sebanyak 250.751 jiwa di Daftar Penduduk Pemilih Pemilu Potensial (DP4), hal ini diprediksi dapat memicu konflik. Dari 
adanya hal demikian, KPU Luwu Utara dalam rapat Koordinasi di Aula Kantor KPU Luwu Utara, jalan simpurusiang, Masamba, Rabu (4/ 9/2012) menyepakati Petugas Pemutakhiran Data Pemilih (PPDP) yang dipantau Panwaslu Kecamatan (Panwascam) turun langsung mengecek kebenaran data pemilih ganda tersebut.

Daftar Pemilih Tetap (DPT) selalu menjadi permasalahan. Dengan adanya 12.072 pemilih ganda yang ditemukan pada DP4, Panwascam Luwu Utara memerintahkan pada seluruh panwascam diwilayah kerja masing-masing untuk mendampingi kerja PPDP yang akan bekerja memutakhirkan data pemilih.

Dalam pemutakhiran data pemilih, hal-hal yang perlu diperhatikan oleh anggota PPDP yang nantinya akan melakukan pemutakhiran dilapangan yaitu usia pemilih yaitu 17 tahun atau sudah menikah, adanya perubahan status anggota TNI atau POLRI menjadi sipil atau sebaliknya, telah meninggal dunia, pindah domisili, dan yang sudah terdaftar tetapi belum memenuhi syarat.

Setelah melakukan identifikasi secara menyeluruh, ketua KPU Luwu Utara, Muhammad Rajab, berbagai persoalan pelik menyangkut DPT, mulai dari yang ganda hingga yang sampai tidak ada orangnya karena sudah meninggal atau pindah domisili. Bukan hanya itu, bahkan ada beberapa nama yang telah lama bermukim di suatu desa ternyata belum memiliki Nomor Induk kependudukan (NIK). Pasalnya, mereka tidak pernah melapor kepada pemerintah desa setempat.

\section{B. KERANGKA TEORITIS}

Kinerja dari kata performance, sering diartikan sebagai hasil kerja atau prestasi kerja. Namun, sebenarnya kinerja mempunyai makna yang lebih luas, bukan hanya hasil kerja, tetapi termasuk bagaimana proses pekerjaan berlangsung (Wibowo,2010:7). Kinerja merupakan hasil pekerjaan yang mempunyai hubungan kuat dengan tujuan strategis organisasi, kepuasan konsumen, dan memberikan konstribusi pada ekonomi (Armstrong dan Baron, 1998:15). Dengan demikian, kinerja adalah tentang melakukan pekerjaan dan hasil yang dicapai dari pekerjaan tersebut. Kinerja adalah tentang apa yang dikerjakan dan bagaimana cara mengerjakannya.

Menurut WJS Purwodarminto,dalam kamus umum bahasa indonesia(1986), kinerja adalah hasil kerja yang di capai oleh seseorang karyawan dalam melaksanakan tugas yang dibebankan kepadanya. Sedangkan pengertian kinerja pegawai menurut Bambang Kusriyanto yang dikutip oleh Harbani Pasolong dalam bukunya "Teori Administrasi Publik", kinerja pegawai adalah hasil kerja perseorangan dalam suatu organisasi (Pasolong, 2007:175). Adapun pengertian kinerja menurut Stephen Robbins yang diterjemahkan oleh Harbani Pasolong, kinerja adalah hasil evaluasi terhadap pekerjaan yang dilakukan oleh pegawai dibandingkan kriteria yang telah ditetapkan sebelumnya. (Pasolong, 2007:176).

Kinerja adalah hasil kerja yang dapat di capai oleh seseorang atau sekelompok orang dalam suatu organisasi sesuai dengan wewenang dan tanggung jawab masing-masing dalam rangka upaya untuk mencapai tujuan organisasi yang bersangkutan secara legal tidak melanggar hukum dan sesuai etika (suyadi,1999:1). Ilyas (2001) mendefinisikan kinerja sebagai penampilan hasil karya personil baik kuantitas maupun kualitas dalam suatu organisasi. Kinerja dapat merupakan penampilan individu maupun kelompok kerja personil. Penampilan hasil karya tidak terbatas kepada personil yang memangku jabatan fungsional maupun struktural, tetapi juga kepada keseluruhan jajaran personil di dalam organisasi.

Menurut Darokah dalam Ilyas (2001) kinerja adalah suatu catatan keluaran hasil pada suatu fungsi jabatan kerja oleh seluruh aktivitas kerja dalam periode waktu tertentu Muchlas (1997) dalam Wulandari (2004) menjelaskan bahwa meskipun seseorang mempunyai kemampuan dan kemauan, tapi mungkin saja ada penghalang yang bisa menghambat prestasinya. Jadi seseorang yang menunjukan kinerja yang tidak baik, maka harus dilihat lingkungan luarnya apakah sudah cukup membantu, seperti apakah 
memiliki kelengkapan peralatan dan bahan, kondisi kerja yang favorable, teman kerja yang membantu, peraturan yang mendukung dan prosedur kerja dengan alokasi waktu yang cukup. Jika semua tidak ada maka jangan diharapkan muncul suatu prestasi kerja yang minimal sekalipun.

Hall TL dan Meija (1987) dalam Ilyas (2001) menyebutkan bahwa faktor yang mempengaruhi kinerja adalah: faktor internal individu yang terdiri dari: (1) karakteristik individu seperti umur, pendapatan, status perkawinan, pengalaman kerja dan masa kerja. (2). Sikap terhadap tugas yang terdiri persepsi, pengetahuan, motivasi, tanggungjawab dan kebutuhan terhadap imbalan, sedang faktor eksternal meliputi sosial ekonomi, demografi, geografi, lingkungan kerja, aseptabilitas, aksesabilitas, beban kerja dan organisasi yang terdiri pembinaan, pengawasan, koordinasi, dan fasilitas.

Menurut Wibowo (2010: 81), terdapat beberapa faktor yang perlu diperhatikan untuk suatu organisasi mempunyai kinerja yang baik, yaitu Manajemen Sumber Daya Manusia, Pengembangan Organisasi, Konteks Organisasi, Desain Kerja, Fungsionalisasi dan Budaya. Budaya merupakan perekat yang mempersatukan organisasi dengan manajemen kinerja. Komponen budaya organisasi adalah nilai-nialai, norma-norma dan gaya manajemen. Nilai-nilai dinyatakan sebagai keyakinan tentang apa yang baik bagi organisasi dan perilaku seperti apa yang diinginkan. Normanorma adalah aturan tidak tertulis yang mendefinisikan harapan atas perilaku, seperti bagaimana manajer memperlakukan bawahan dan bagaiman bawahan berhubungan dengan manajer. Sedangkan, gaya manajemen menjelaskan bagaimana manajer berperilaku dan menjalankan kekuatan dan kekuasaannya.

Pengukuran kinerja aktivitas didisain untuk menilai aktivitas tersebut dilaksanakan dan hasil yang diperoleh.Kinerja atau prestasi yang diraih oleh suatu organisasi dapat dilihat dari beberapa aspek sebagai berikut:

\section{a. Aspek Responsivitas}

Aspek Responsivitas disini adalah kemampuan provider untuk mengenali kebutuhan masyarakat, menyusun agenda dan prioritas pelayanan, serta mengembangkan programprogram pelayanan sesuai dengan kebutuhan dan aspirasi masyarakat.

\section{b. Aspek Profesionalisme}

Aspek Profesionalisme menunujukkan sifat dari suatu pekerjaan yang membutuhkan kompetensi atau keahlian teknis. Profesionalisme menjadi suatu kebutuhan yang tidak dapat dihindari oleh para pengelola organisasi karena semakin tumbuhnya kompleksivitas masalah-masalah yang ada dalam masyarakat dan semakin canggih perkembangan ilmu pengetahuan dan teknologi.

\section{c. Aspek Produktivitas}

Konsep Produktivitas tidak hanya mengukur tingkat efisiensi, tetapi juga efektivitas pelayanan. Produktivitas umumnya dipahami sebagai rasio antara input dan output.

\section{d. Aspek Akuntabilitas (Accountability)}

Aspek ini di artikan sebagai pertanggungjawaban dari para aparatnya tentang apa yang telah dilakukan terhadap pihak yang berkepentingan. Konsep ini mengarah kepada pengertian bahwa segala tindakan organisasi akan dinilai dan dievaluasi oleh kalangan yang terkait atau memilki kepentingan.

\section{e. Kerja Sama}

Dalam suatu organisasi berbasis tim, pencapaian kinerja organisasi sangat di tentukan oleh kinerja tim yang terdiri dari sekelompok orang dengan latar belakang budaya berbeda dan kompetensinya bervariasi, ditentukan oleh kemampuannya bekerja sama.

\section{f. Aspek Kualitas Pelayanan}

Merupakan efektivitas pelayanan yang diberikan oleh organisasi menyangkut aspek quality services (kualitas pelayanan).

Berdasarkan Undang-undang Republik Indonesia Nomor 15 Tahun 2011, tentang penyelenggara Pemilihan Umum, Komisi pemilihan umum, selanjutnya di singkat KPU adalah lembaga penyelenggara pemilihan umum yang bersifat nasional, tetap, dan 
mandiri yang bertugas melaksanakan pemilihan umum. KPU Provinsi dan KPU Kabupaten/ Kota adalah penyelenggara pemilu di Provinsi atau Kabupaten/Kota.Wilayah kerja KPU meliputi seluruh wilayah Negara Kesatuan Republik Indonesia. KPU menjalankan tugasnya secara berkesinambungan dan dalam menyelenggarakan Pemilu, KPU bebas dari pengaruh pihak mana pun berkaitan dengan pelaksanaan tugas dan wewenangnya. KPU berkedudukan di Ibu Kota Negara Republik Indonesia, KPU Provinsi berkedudukan di Ibu Kota Provinsi dan KPU Kabupaten/Kota berkedudukan di Ibu Kota Kabupaten/Kota.

Seluruh anggota KPU dan perangkat pendukungnya menyadari bahwa rakyat menginginkan pemilihan umum saat ini dan kedepannya lebih berkualitas dari pemilihan umum sebelumsebelumnya. Oleh karena itu, dalam penyelenggaraan pemilu saat ini dan kedepannya KPU harus mampu menyelenggarakan pemilu dengan mengedepankan asas-asas penyelenggara pemilu, yaitu: mandiri, jujur, adil, kepastian hukum, tertib, kepentingan umum, keterbukaan, proporsionalitas, propesionalitas, akuntabilitas, efisiensi dan efektifitas.

KPU Daerah Kabupaten Luwu Utara adalah lembaga negara yang menjalankan agendaagenda negara sesuai dengan Undang-Undang yang berlaku seperti Pemilihan Umum legislatif, Pemilihan Umum Presiden dan Wakil Presiden, serta Pemilihan Umum Kepala Daerah (Pilkada) khususnya di wilayah Kabupaten Luwu Utara.

Pemutakhiran data pemilih adalah rangkaian kegiatan yang terencana yang dilakukan oleh panitia pemungutan suara (PPS) di bantu petugas pemutakhiran data pemilih (PPDP) dalam rangka penyusunan Daftar Pemilih Sementara (DPS), Daftar Pemilih Sementara Hasil Perbaikan (DPSHP), dan Daftar Pemilih Tetap (DPT). Pemutakhiran data pemilih yaitu pendataan pemilih dengan menggunakan data pemilih terakhir yang ada di setiap KPU Daerah. Hasil pemutakhiran data pemilih digunakan sebagai bahan penyusunan daftar pemilih sementara. Pemutakhiran data pemi-lih ini memiliki dua jenis, yaitu pemutakhiran di belakang meja (on desk), dan verifikasi faktual. Pemutakhiran on desk dilakukan dengan cara memeriksa dan mencocokkan DPT pemilu terakhir yang dimiliki KPU dimutakhirkan berdasarkan DP4 mutakhir dari pemerintah/ pemerintah daerah. Pemutakhiran on desk dapat dilakukan dengan dua tipe, yaitu berkelanjutan (dalam jangka waktu tertentu tiap tahun), dan secara periodik menjelang penyelenggaraan pemilu tertentu.

Pemutakhiran Verifikasi faktual (door to door) dilakukan dengan tiga cara. Pertama, PPS dan PPDP mendatangi masing-masing keluarga, memverifikasi dan memberikan tanda (stiker \& formulir telah didaftar). Kedua, hasil pemutakhiran disahkan oleh petugas secara bertingkat (PPDP, PPS, PPK, KPU Kab/Kota) di tandai dengan pemberian tanda tangan dan stempel lembaga. Ketiga, DPT Pemilu terakhir diserahkan kepada pemerintah/ pemerintah daerah sebagai bahan pemutakhiran data kependudukan.

Pemilihan kepala daerah adalah upaya demokrasi untuk mencari pimpinan daerah yang berkualitas dengan cara-cara yang damai, jujur dan adil. Pilkada menurut UU No. 32/ 2004 tentang pemeritahan daerah adalah "Bahwa pelaksanaan pilkada langsung pada hakikatnya tidak hanya untuk tujuan mengoptimalkan demokratisasi di daerah, melainkan merupakan perwujudan dari prinsip otonomi daerah seluas-luasnya".

Dan pasal 56 ayat 1 UU No. 32 tahun 2004 berbunyi : kepala daerah dan wakil kepala daerah dipilih dalam satu pasangan calon yang dilak-sanakan secara demokratis berdasarkan asas langsung, umum, bebas, rahasia, jujur, dan adil.

Lahirnya UU No.32 tahun 2004 mengenai Pemerintahan Daerah yang memuat ketentuan tentang Pemilihan Kepala Daerah secara langsung adalah merupakan proses penentuan pilihan masyarakat terhadap calon yang mereka akan angkat sebagai pemimpin daerah mereka. Proses yang dimaksudkan dalam hal ini tetap dikemas dalam sebuah mekanisme sebagaimana pemilihan umum. Dalam pemilihan kepala daerah masyarakatlah yang kini memegang kunci. Mereka bisa menentukan dan sekaligus langsung untuk memilih calon yang mereka anggap paling tepat.

Pemilihan kepala daerah secara langsung adalah momentum yang paling strategis untuk 
memilih kepala daerah yang berkualitas. Keberhasilannya tidak hanya diukur dari proses penyelenggaraannya yang berlangsung lancar dan damai tetapi juga diukur dari hasil yang diperoleh, apakah telah menghasilkan pemimpin yang berkualitas terutama dari sisi manajerial dan kompetensi. Bila pemilihan ini hanya dijadikan sebagai ajang perebutan kekuasaan melalui mekanisme voting yang hanya popular dan diterima secara luas, namun tidak mempunyai kecakapan dan kemampuan dalam mengelola daerah.

Pemerintahan daerah adalah pelaksanaan fungsi-fungsi pemerintahan daerah yang dilakukan oleh lembaga pemerintahan daerah yaitu Pemerintah Daerah dan Dewan Perwakilan Derah (DPRD).Secara umum kepala daerah adalah kepala pemerintah daerah yang dipilih secara demokratis.Kepala daerah dalam melaksanakan tugasnya dibantu oleh seorang wakil Kepala Daerah, dan perangkat daerah (UU No. 32/2004 tentang Pemerintahan Daerah). Semua tingkatan daerah di Indonesia diberikan hak untuk menyelenggarakan pemilihan kepala daerah secara langsung, dengan tujuan agar rakyat di daerah yang bersangkutan dapat secara bebas dan bertanggungjawab memilih kepala daerahnya yang berkualitas.

Penilaian terhadap kinerja dalam suatu organisasi merupakan kegiatan yang sangat penting bagi setiap organisasi artinya penilaian merupakan alat yang digunakan untuk mengukur tingkat keberhasilan suatu organisasi dalam waktu tertentu. Dalam penilaian yang dilakukan juga akan menjadi input untuk perbaikan serta peningkatan kualitas dalam suatu organisasi serta pelayanannya dalam masyarakat. Untuk itu peningkatan dalam pelaksanaan kinerja harusnya diperhatikan agar dalam pencapaian hasil kerja dapat lebih maksimal serta sesuai dengan harapan sebuah organisasi dan masyarakat pada umumnya.

Guna mengukur tingkat pelaksanaan kinerja Komisi Pemilihan Umum Daerah Kabupaten Luwu Utara, kita dapat melihat bagaimana kinerja dalam pelaksanaan tugas dan wewenangnya, apakah sesuai dengan peraturan yang berlaku ataukah menyimpang dari peraturan yang ditetapkan. Berdasarkan pengalaman, pengamatan, serta informasi yang ditemukan, menggambarkan bahwa kinerja KPU Daerah Kabupaten Luwu Utara belum sepenuhnya efektif. Di mana pada proses pemilihan sebelumnya masih banyak masyarakat yang tidak melakukan pemilihan, hal ini di karenakantidak adanya kartu pemilih yang diterima, serta adanya kartu pemilih yang diperuntukkan bagi masyarakat yang sudah meninggal dan belum wajib pilih.

Adanya hal-hal seperti ini, walaupun relatif kecil di khawatirkan akan menghambat dan mengganggu pelaksanaan pemilu. Hal ini di khawatirkan menimbulkan kerawanan konflik di setiap daerah yang mengganggu pelaksanaan pemilu serta dapat merugikan pemerintah dan masyarakat itu sendiri. Keberhasilan sebuah kebijakan dalam pelaksaan kerja demi tercapainya kinerja yang baik, perlu dipertimbangkan beberapa indikator yang digunakan sebagai dasar pengukuran dalam penilaian. Indikator-indikator tersebut menjadi tolak ukur pelaksanaan kinerja Komisi Pemilihan Umum (KPU) Daerah Kabupaten Luwu Utara pada pemilukada (Gubernur dan Wakil Gubernur) tahun 2013. Terkait dengan pemaparan tersebut, maka indikator yang dibutuhkan penyusun dalam penelitian ini adalah: (1) aspek responsivitas, (2) aspek profesionalisme, (3) aspek produktifitas, (4) aspek akuntabilitas, (5) aspek kerjasama, (6) aspek kualitas pelayanan.

\section{METODE PENELITIAN}

Penelitian ini dilaksanakan di wilayah Kabupaten Luwu Utara khususnya pada KPU Daerah Kabupaten Luwu Utara. Lokasi ini didasarkan atas pertimbangan bahwa lokasi tersebut merupakan asal daerah penyusun yang kemudian bertujuan mengetahui kinerja dari KPU Kabupaten Luwu Utara dalam pemutakhiran data pemilih pada pemilukadaProvinsi Sulawesi selatan. Jenis penelitain yaitu penelitian survei langsung ke objek penelitian dengan tipe deskriftif kualitatif yaitu suatu penelitian yang memberikan gambaran secara sistematis, faktual mengenai berbagai macam data yang telah dikumpulkan 
dari objek penelitian (Lapangan) yang berkaitan dengan masalah tentang kinerja KPU Kabupaten Luwu Utara dalam pemutakhiran data pemilih pada pemilihan Gubernur dan Wakil gubernur Sulawesi selatan Tahun 2013. Informan adalah penyidik dan pemberi infrmasi dan data. Dalam hal ini, informan yang dimaksud adalah orang yang dianggap banyak mengetahui tantang kinerja KPUD kabupaten Luwu Utara dalam pemutakhiran data pemilih pada pemilihan Gubernur dan Wakil Gubernur Sulawesi Selatan, baik yang melakukan pendataan atau pemutakhiran maupun masyarakat yang di data untuk ditetapkan sebagai pemilih pada pemilihan Gubernur dan wakil gubernur Sulawesi Selatan.Adapun informan yang ditetapkan adalah sebagai berikut : Ketua KPU Kabupaten Luwu Utara, Panwaslu Kecamatan, Anggota PPDP Desa Baloli, Anggota PPDP Kelurahan Kappuna, Anggota PPDP Desa Laba, Anggota Partai Politik dan Tokoh Masyarakat. Jenis Data pada penelitian ini: kualitatif dan Data Kuantitatif adalah data yang diperoleh dalam bentuk angka-angka yang kemudian diolah dan dibuatkan suatu interpretasi dalam upaya menjawab permasalahan yang ada. Sumber Data : Data Primer dan Data Sekunder Teknik Pengumpulan Data: Studi Kepustakaan, Observasi dan Wawancara. Analisis data dari penelitian kinerja KPUD Kabupaten Luwu Utara dalam pemutakhiran data pemilih pada pemilihan gubernur dan wakil gubernur Sulawesi selatan tahun 2013, baik yang diperoleh dengan data primer maupun data sekunder dilakukan secara deskriptif kualitatif dengan memperhatikan hasil wawancara dan dengan melihat hasil penetapan pemilih dari pemutakhiran yang dilaksanakan.

\section{HASIL PENELITIAN DAN PEMBAHASAN}

\section{Kinerja Komisi Pemilihan Umum Kabupaten Luwu Utara Dalam Pemutakhiran Data Pemilih}

Komisi Pemilihan Umum Daerah kabupaten Luwu Utara merupakan organisasi penyelenggara pemilihan umum, baik pemilihan legislatif, presiden maupun kepala daerah, khusus- nya di daerah kabupaten luwu utara. Namun saat ini penyelenggaraan pemilihan yang dimaksud adalah penyelenggaraan pemilihan gubernur dan wakilnya atau kepala daerah dan wakil kepala daerah provinsi sulawesi selatan. Dimana KPUD Luwu Utara merupakan penyelenggara pemilihan umum daerah kabupaten dalam wilayah provinsi dengan memperhatikan keputusan KPU Provinsi.

Dalam penyelenggaraan pemilihan, KPU Kabupaten Luwu Utara melaksanakan pemilihan sebagaimana apa yang ada pada keputusan KPU Provinsi, mulai dari tahapan, program dan jadwal penyelenggaraannya. Sesuai dengan tahapan pelaksanaanya yang dikaji lebih dalam yaitu tentang pemutakhiran data pemilih, mulai dari tahapan, pelaksanaan hingga hasil pemutakhiran data pemilih dengan kata lain penetapan daftar pemilih tetap dalam pemilihan.

Berdasarkan observasi di lapangan untuk melakukan pemutakhiran data pemilih mulamula menentukan anggota atau siapa-siapa saja yang berhak melakukan pendataan pemutakhiran kepada masyarakat untuk ditetapkan sebagai pemilih. Sebelum melakukan pemutakhiran, terlebih dahulu KPU Kabupaten menentukan atau melakukan pemilihan, pengangkatan anggota PPK, PPS, PPDP dan KPPS. Setelah tahapan pembentukan dan pengangkatan anggota, kemudian diadakan pelatihan menganai hal-hal yang perlu diperhatikan dalam melakukan pendataan masyarakat yang berhak dan sudah wajib pilih untuk ditetapkan sebagai pemilih dalam pemilihan.

\section{Responsivitas}

Responsivitas merupakan kemampuan mengenali kebutuhan masyarakat serta pengembangan pelayanan sesuai kebutuhan dan aspirasi.

Hasil wawancara penulis dengan Ketua KPU Kabupaten Luwu Utara, mengenai hal-hal yang dilakukan dalam pelaksanaan pemutakhiran data pemilih:

"Untuk melakukan pemutakhiran data, terlebih dahulu kami memberikan pemberitahuan kepada pemerintah daerah tentang penyampaian Data Penduduk Potensial Pemilih Pemilihan (DP4), setelah menerima DP4 dari pemerintah daerah kemudian kita menyusun 
data berdasarkan DP4 tersebut dan di buat sebanyak PPS dan RT/RW untuk di sampaikan kepada PPS, PPDP melalui PPK dalam melakukan pengecekan kepada masyarakat dari pintu ke pintu untuk di tetapkan sebagai pemilih. Namun, sebelum mengesahkannya sebagai pemilih tetap kita mengesahkannya sebagai pemilih sementara untuk menindaklanjuti apakah masih ada data tambahan atau tidak, intinya kita melaksanakan sesuai tahapan pelaksanaan"( M R.12 Desember 2012).

Berdasarkan hasil wawancara, menggambarkan adanya responsivitas dari angggota KPU selaku penyelenggara pemilihan dimana pada wawancara menggambarkan adanya pelaksanaan berdasarka ketentuan dan ketetapan berdasarkan perundang-undangan yang sebelumnya ditetapkan untuk di jadikan pedoman pelaksanaan pemilihan.

\section{Profesionalisme}

Terkait dengan hal ini, yang merupakan sifat dari suatu pekerjaan yang membutuhkan kompetensi atau keahlian teknis dalam melaksanakan pekerjaan, KPU serta pemerintah daerah memiliki predikat tersendiri karena mampu memilih anggota piawai dan mau bekerja untuk pemutakhiran data pemilih, serta ini dengan adanya bantuan dan bimbingan yang dilakukan sebelum melakukan pemutakhiran dilapangan.

Hasil wawancara penulis dengan anggota PPDP Kelurahan Kappuna Kecamatan Masamba Kabupaten Luwu Utara:

"Saya melakukan pendataan berdasarkan TPS penempatan, mengunjungi rumah penduduk dengan memperhatikan usia dan status sesuai dengan yang tertera pada kartu keluarga, kemudian juga menanyakan apakah ada yang berubah status dalam KK, baik yang menjadi anggota kepolisian maupun yang sudah menikah. Bila ada, kita tetap mencatat namun dengan keterangan bahwa dia adalah anggota kepolisian. Setelah kita mendata laporan kemudian diserahkan kepada kelurahan untuk diteruskan ke kantor KPU" ( I K. 21 Desember 2012 ).

Berdasarkan pendataan yang dilakukan anggota PPDP dalam melakukan pemutakhiran data dengan memperhatikan status masyara- kat dan usia dari masyarakat yang di temui di rumah masing-masing, kemudian di data untuk ditetapkan dan digolongkan dalam nama-nama yang berhak dan termasuk dalam golongan pemilih untuk dilaporkan dan ditetapkan sebagai pemilih pada pemilihan. Hal ini dilakukan dan diperhatikan sesuai dengan ketetapan yang disampaikan dalam pelatihan dan bimbingan tekhis pendataan untuk pemutakhiran data.

\section{Produktivitas}

Dengan melihat rekapitulasi daftar pemilih sementara Pemilihan Gubernur dan Wakil Gubernur tahun 2013 yang ditetapkan oleh KPU Kabupaten Luwu Utara, kita dapat melihat produktifitas atau hasil dari adanya pelayanan KPU kabupaten dari adanya data yang dikelola berdasarkan kerja PPDP dalam melakukan pendataan demi terselenggaranya pemilihan.

Hasil wawancara penulis dengan salah satu anggota Partai PKB Kabupaten Luwu Utara:

"Mengenai produktivitas, kita belum bisa mengambil kesimpulan yang pasti, dimana produktivitas merupakan seberapa besar hasil pelayanan yang dilakukan.Saat ini selain data sementara yang saya ucapkan tadi, KPU juga sudah menetapkan data pemilih tetap.Namun, menjadi pertanyaan, apakah dalam pemilihan nanti, pemilih yang ditetapkan ini semua jelas adanya ataukah masih banyak data yang keliru yang ketepatannya belum tepat sasaran. Ini yang nanti kita akan ketahui saat pemilhan berlangsung. (R B. 27 Desember 2012).

Berdasarkan hasil wawancara dengan salah satu anggota partai politik di daearah kabupaten luwu utara, menandakan adanya kekhawatiran dengan data pemilih yang telah ditetapkan oleh anggota KPU yang notebenenya dalam hal ini sebagai pemilih tetap dalam pemilihan pada 22 Januari.

\section{Akuntabilitas.}

Dengan adanya rekapitulasi ini pula, kita dapat melihat bahwa inilah akuntabilitas atau pertanggungjawaban kerja KPU baik kepada masyarakat maupun kepada calon yang akan dipilih dalam pemilihan nantinya. Sekalipun disadari ini hanya rekapitulasi yang sementara. 
Namun, inilah kerja KPU dalam dan demi mensukseskan pemilihan.

Dari rekapitulasi sementara, KPU juga menghimbau pada masyarakat agar kiranya yang belum terdaftar dalam rekapitulasi pemilih sementara agar kiranya melaporkan diri agar dicocokkan kembali dan dapat diperbaharui sebelum ditetapkannya daftar pemilih tetap.

Hasil wawancara penulis dengan salah satu anggota Partai PKB Kabupaten Luwu Utara:

"Terkait dengan adanya rekapitulasi pemilih sementara yang ditetapkan KPU, ini belum bisa dijadikan sebagai tolak ukur berhasilnya atau efektifnya kinerja KPU dalam melakukan pendataan atau pemutakhiran data pemilih. Namun harus diketahui bahwa inilah hasil kerja sementara yang juga merupakan bentuk pertanggung jawaban kerja demi tercapainnya data yang lebih valid, olehnya diharapkan pula partisipasi dari masyarakat, karena harus diketahui tanpa kerjasama kita semua, ini tidak akan berjalan dengan makasimal. (R B. 27 Desember 2012).

Berdasarkan hasil weawancara, terkait tentang akuntabilitas atau pertanggungjawaban oleh anggota KPU dalam melakukan pendataan atau pemutakhiran data pemilih, salah seorang anggota partai politik PKB Kabupaten luwu utara saat ditemui menyatakan dan mengakui bahwa inilah bentuk kerja dari pada anggota KPU dalam pemutakhiran data, yaitu menetapkan pemilih yang nantinya akan menjadi seorang pemilih pada pemilihan. Namun, dari pernyataannya juga terlihat harapan besar kepada masyarakat untuk ikut berpartisipasi demi kelancaran dan kesuksesan pemilihan agar apa yang dikhawatirkan tidak terjadi dan pada saat pemilihan tidak terjadi pertikaian seperti halnya pada pemilihan yang sebelumnya.

\section{Kerjasama}

Berbicara mengenai kerjasama, yang dimaksud dalam hal ini adalah bagaimana kerjasama antara KPU Kabupaten dan Panwas dalam penyelenggaraan pemilihan Gubernur dan wakil Gubernur Sulawesi Selatan tahun 2013 selaku penyelenggara pemilu. Yaitu, mulai dalam tahap awal hingga usainya pemilihan dilaksanakan. Namun, yang jauh lebih dalam yaitu dalam hal pemutakhiran data yang nantinya akan melakukan pemilihan pada 22 januari 2013. Terkait penulis meninjauh tentang bagaimana kinerja KPU dalam melakukan pemutakhiran data.

Hasil wawancara penulis dengan Anggota panwas kecamatan Masamba terkait hubungan kerjasama dengan KPU Kabupaten Luwu Utara:

"Hubungan kerjasama diantara kami selaku penyelenggara pemilu, panitia pengawas pemilihan dengan KPU sebenarnya baik, namun kurang komunikasi, dan juga ada sedikit kerancuan terkait dalam pengambilan data dikantor KPU. Dimana pada saat saya ke kantor untuk pengambilan data, KPU tidak langsung memberikan data yang kita inginkan, malahan kadang kita di suruh untuk menulisnya sendiri. Padahal sebenarnya rekapan tersebut sudah ada, ini juga mengenai UU Pemilu kurang tegas serta sosialisasi kurang, contohnya; banyaknya baliho yang terpasang tidak sesuai aturan."(Y S. 07 Januari 2013).

Dari hasil pengamatan dilapangan mengenai kerjasama antara KPU dan Panwas menunjukkan bahwa kurangnya komunikasi selaku penyelenggara pemilu ini nantinya akan mempengaruhi kinerja lembaga tersebut. Penulis sendiri tidak mampu menarik atau memberi komentar terkait kurangnya komunikasi antara dua lemabaga tersebut. Namun dari hasil wawancara dengan salah seorang Anggota Panwas kecamatan menunjukkan benar adanya hal demikian.

\section{Kualitas Pelayanan}

Kualitas pelayanan dalam hal ini kita maksudkan yaitu bagaimana keadaan dan pola perilaku anggota KPU beserta jajarannya memberi pelayanan kepada masyarakat yang berkunjung ke kantor dan bagaimana perilaku angggota PPDP yang melakukan pendataan kepada masyarakat. Baik dalam bentuk pendataan untuk di daftar sebagai pemilih maupun dalam hal sosialisasi kepada masyarakat terkait adanya Pemilihan Gubernur dan Wakil Gubernur Sulawesi Selatan pada tanggal 22 Januari 2013. 
Hasil wawancara penulis dengan salah seorang tokoh masyarakat, desa rompu terkait pola perilaku anggota PPDP dalam melakukan pendataan:

"Perilaku dari yang melakukan pendataan untuk ditetapkannya saya sebagai pemilih cukup baik, dimana saat iya datang menjelaskan apa tujuan kedatangannya kemudian meminta kartu keluarga untuk dilihat siapa-siapa yang akan nantinya terdaftar selaku pemilih". ( $S$ B. 12 Januari 2013).

Berdasarkan keadaan dilapangan selama penulis melakukan penelitian terlihat adanya keramahan dari anggota KPU beserta jajarannya, hal ini menggambarkan dari adanya beberapa masyarakat yang hadir di kantor KPU untuk beberapa keperluan serta penulis sendiri yang selama penelitian berlangsung berada di kantor KPU.

Kualitas pelayanan, sebenarnya juga erat kaitanya dengan produktivitas dan akuntabilitas dimana produktivitas disini yaitu seberapa besar pelayanan itu memiliki hasil, adapun juga akuntabilitas yaitu, bagaimana pertanggungjawaban dari apa yang dilaksanakan kepada pihak yang berkepentingan, dalam hal ini tidak hanya calon dan partai pengusung saja, namun sebenarnya yang utama adalah masyarakat.

\section{Faktor Pendukung dan Penghambat Dalam Pemutakhiran Data Oleh KPU Kabupaten Luwu Utara.}

\section{Faktor Pendukung}

\section{a. Sumber Daya Manusia (SDM)}

Hasil wawancara penulis dengan Ketua KPU Kabupaten Luwu Utara, mengenai faktor yang mendukung dalam pemutakhiran data pemilih:

"Dalam pemutakhiran data pemilih yang mendukung yaitu SDM, namun ini juga menjadi penghambat, mendukungnya yaitu adanya staf yang sudah mahir dalam melakukan pemutakhiran yang sudah memiliki pengalaman kerja serta pendidikannya yang mendukung pula" (M R. 12 Desember 2012 ).
Berdasarkan hasil wawancara di atas, menunjukkan bahwa dalam pemutakhiran data pemilih, Sumber Daya Manusia merupakan faktor yang menjadi pendukung sekaligus menjadi penghambat, dimana mendukungnya yaitu adanya SDM yang sudah berpengalaman melakukan pemutakhiran dan adanya strata pendidikan yang tinggi.

\section{b. Loyalitas Anggota PPDP dan Staf}

Loyalitas angggota dan staf dalam melakukan pekerjaan baik yang berada di kantor KPU maupun yang bekerja dilapangan untuk pemutakhiran data pemilih, ini merupakan faktor pendukung dalam pelaksanaan kerja KPU.

Hasil wawancara penulis dengan anggota KPU Kabupaten Luwu Utara terkait hal yang mendukung pemutakhiran data:

"Dalam pemutakhiran data pemilih, kita mengakui bahwa loyalitas anggota merupakan indikator yang menjadi pendukung dalam pemutakhiran data. Baik yang berada di kantor maupun yang bekerja dilapangan. Contohnya anggota PPDP yang dengan kerja kerasnya melakukan pemutakhiran dengan melakukan pendataan kepada masyarakat wajib pilih secara door to door". ( S R. 18 Desember 2012).

Hal ini menunjkkan adanya anggota KPU yang mengakui atas keloyalan anggota PPDP yang senantiasa bekerja kesar melakukan pemutakhiran data dilapangan demi terselenggaranya pemilihan dan ketepatan daftar pemilih yang akan meilih dalam pemilihan.

\section{c. Kerja sama}

Untuk mencapai sebuah hasil yang baik dalam pelaksanaan kerja yang berbentuk tim atau kelompok organisasi, kerjasama merupakan alat untuk memudahkan tercapainya hasil yang baik. Dalam pemutakhiran data pemilih oleh KPU Kabupaten Luwu Utara selaku lembaga Negara kerjasama antar Ketua, anggota dan staf serta pamwas merupakan faktor pendukung mutakhirnya data pemilih.

Hasil wawancara dengan anggota KPU Luwu Utara terkait hubungan kerja sama antar anggota dan panwas:

"Mutakhirnya data pemilih, ini Alhamdulillah berkat kerjasama antar anggota, ketua, staf 
serta panwas selaku pengawas dalam pemutakhiran. Tanpa adanya hubungan kerja sama dalam pelaksanaan tugas, ini tidak akan terjadi. Artinya tanpa adanya pengawasan oleh panwas pemutakhiran dilapangan tidak akan berjalan secara maksimal dan juga tanpa kerja keras anggota PPDP, mutakhirnya data akan terhambat. (S R. 18 Desember 2012).

Berdasarkan hasil wawancara, faktor kerjasama merupakan faktor penentu terselenggaranya pemilihan yang sebagaimana diharapkan bersama dimana hal ini merupakan hal yang dapat mempermudah dan meringankan kerja dalam pencapaian hasil yang maksimal.

\section{Faktor Penghambat}

\section{a. Sumber Daya Manusia (SDM)}

Sumber daya manusia, sebagaimana menurut guess dalam Armstrong dan baron (1998:17) pada faktor pendukung di atas, telah dijelaskan tentang praktik kinerja tinggi manajemen sumber daya manusia dilakukan melalui beberapa bagian.

Hasil wawancara penulis dengan Ketua KPU Kabupaten Luwu Utara:

"Dalam pemutakhiran data pemilih, SDM seperti yang saya katakana tadi, merupakan faktor yang mendukung sekaligus menghambat. Mendukungnya ya, seperti apa yang tadi saya katakan. Adapun menghambatnya yaitu, ratarata pendidikan anggota PPDP itu hanya sebatas SMA, yang memiliki pengalaman kerja kurang. Namun sebelum terjun ke lapangan untuk pemutakhiran terlebih dahulu kita mengadakan bimbingan tentang hal yang perlu diperhatikan dalam melakukan pemutakhiran. (M R. 12 Desember 2012)

Berdasrkan survei dilapangan, anggota PPDP yang melakukan pemutakhiran data hanya sebagian kecil merupakan sarjana dan ahli madya.Hal inilah yang kemudian dikhawatirkan dalam melakukan pemutakhiran, apalagi mayoritas dari anggota PPDP belum cukup memiliki pengalaman dan pemahaman terkait hal yang nantinya perlu diperhatikan dalam melakukan pemutakhiran, sekalipun diketahui bahwa sebelumnya telah dilakukan bimbingan. b. Data Penduduk Potensial Pemilih Pemilu (DP4)

Dalam pemutakhiran data adanya penggunaan data penduduk yang baru merupakan faktor yang mempersulit atau menghambat untuk pemutakhiran data, dimana adanya perubahan jumlah penduduk dan perubahan status masyarakat yang sewaktu-waktu dapat berubah.

Hasil wawancara penulis dengan ketua KPU Kabupaten Luwu Utara terkait dengan hal yang menghambat pemutakhiran data pemilih:

"Kelemahan pemutakhiran data dalam pelaksanaan pemilihan baik pemilihan yang sebelumnya maupun pemilihan gubernur yang dilaksanakan pada 22 Januari, yaitu adanya data pemilih yang tidak digunakan secara berkelanjutan, melainkan kita melakukan pengolahan data baru, yang kesemuanya bercampur antara yang berhak memilih dan yang belum memenuhi syarat untuk menjadi pemilih pada pemilihan. ". (M R. 07 Januari 2013).

Melihat dari hasil wawancara, ini menggambarkan bahwa pemerintah daerah dan KPU kurang komunikasi dan yang memperlihatkan hubungan kerja sama yang kurang baik dalam pengolahan data yang nantinya akan ditetapkan sebagai pemilih pada pemilihan.

\section{c. Kurangnya Partisipasi Masyarakat}

Dalam proses pemutakhiran data, kurangnya partisipasi masyarakat ini kemudian menjadi kendala diperolehnya data yang falid dan benar adanya.

Hasil wawancara penulis dengan Ketua KPU Kabupaten Luwu Utara terkait partisipasi masyarakat:

"Beberapa faktor yang menyebabkan terjadinya tumpang tindih pemilih. Misalnya, warga yang sudah meninggal dunia tetapi tidak pernah dilaporkan kepada pemerintah setempat sehingga namanya masih ada dalam DPT. Di sisi lain, tidak sedikit warga yang mengurus KTP hanya untuk suatu saat di suatu desa hinggga akhirnya menyebabkan jumlah data membengkak, sementara orangnya tidak berada di tempat. (M R. 07 Januari 2013). 
Berdasarkan hasil wawancara diatas, ini menggambarkan peran masyarakat serta pemerintah yang kurang berperan aktif, masyarakat misalnya, bila mana ada keluarga yang lahir atau meninggal tidak dilaporkan pada pemerintah setempat, namun bisa jadi pemerintah setempat yang tidak mensosialisasikan pada masyarakat bahwa hal demikian bila mana terjadi agar dilaporkan pada pemerintah setempat, agar jumlah penduduk dapat diketahui secara pasti.

\section{d. Anggaran}

Anggaran merupakan hal yang juga manjadi penghambat, dimana ini bagi anggota PPDP yang melakukan pendataan dilapakan yang hanya memperoleh honor yang minim, yang kemudian harus mendata masyarakat dari pintu kepintu.

Dengan harus mendatangi masyarakat dari pintu kepintu, yang keberadaannya belum tentu berada di rumah masing-masing membuat lambatnya anggota PPDP melakukan pemutakhiran.

Hasil Wawancara dengan anggota PPDP desa Laba, terkait kendala yang dilakukan dalam melakukan pendataan:

"Terus terang dalam melakukan pendataan pada masyarakat honor buat kita, itu sangat minim. Padahal kita dari rumah kerumah, yang kadang, rumah yang kita kunjungi itu tidak ada orangnya, kita harus berulang-ulang untuk bertemu dengan dia, dan bahkan kita harus jalan malam untuk melakukan pendataan, berhubung pada siang masyarakat jarang dirumah karena bekerja (M D. 15 Desember 2012).

Berdasarkan survei dilapangan melihat keadaan wilayah yang rumah penduduk jaraknya berjauhan hal ini menunjukkan bahwa anggota PPDP harus bekerja keras. Namun dengan mengatakan bahwa kurangnya honor buat mereka memang harus diperhitungkan.

\section{e. Luas Wilayah}

Kabupaten Luwu Utara diketahui memiliki Luas Wilayah yang cukup besar, dalam melakukan pendataan untuk pemutakhiran data pemilih ini sangat menghambat, karena data yang seharusnya diterima dalam sehari harus menjadi dua atau tiga hari.
Hasil wawancara dengan ketua KPU Kabupaten Luwu Utara:

"Faktor wilayah merupakan salah satu faktor yang menghambat dalam melakukan pemutakhiran data, dimana melihat daerah kabupaten luwu utara yang daerah desanya seperti rampi dan seko itu sangatjauh dan juga jaringan telekomunikasi untuk kesana sangat sulit.Ini kemudian menjadi salah satu penghambat kita dalam melakukan pemutakhiran data. Karena data yang seharusnya diterima hari ini itu karus diterima satu atau dua hari kedepan(M R. 07 Januari 2013).

Berdasarkan survei dilapangan, melihat wilayah luwu utara, desa pedalaman dan lokasi kantor KPU itu sanga jauh, ini kemudian menjadi kendala bagi kepala desa atau anggota PPDP untuk melaporkan hasil pemutakhiran data pemilih menjadi sulit, ditambah sulitnya jaringan komunikasi di darah tersebut.

\section{E. KESIMPULAN}

Kinerja Komisi Pemilihan Umum Kabupaten Luwu Utara dalam konteks pemutakhiran data pemilih pada pemilihan Gubernur dan Wakil Gubernur Sulawesi Selatan tahun 2013 telah berjalan dengan baik namun sepenuhnya belum efektif. Hal ini dibuktikan dengan banyaknya masyarakat luwu utara yang seharusnya terdaftar sebagai pemilih pada pemilihan, tidak mendapat surat panggilan untuk melakukan pemilihan, dan sebaliknya banyaknya surat panggilan yang ditujukan pada orang-orang yang keberadaannya dalam suatu daerah tidak diketahui oleh masyrakat setempat, sehingga surat panggilan tersebut tinggalah menumpuk dan tak dipergunakan.

Faktor pendukung dan penghambat kinerja Komisi Pemilihan Umum dalam pelaksanaan pemutakhiran yaitu: Faktor Pendukung: Sumber daya manusia (SDM), Loyalitas anggota PPDP dan staf dan Kerjasama. Faktor Penghambat: Sumber daya manusia (SDM), Data Penduduk Potensial Pemilih Pemilu (DP4), Kurangnya Partisipasi Masyarakat, Anggaran dan Luas wilayah. 


\section{DAFTAR PUSTAKA}

Arifin, Anwar, 2011. Komunikasi Politik (Filsafat-Paradigma-Teori-Tujuan Strategi dan Komunikasi Politik Indonesia), Jakarta: Graha Ilmu.

Armstrong, Michael and Angela Baron, 1998. Performance Management. London: Institute of Personnel And Development.

As'ad, M., 2003, Psikologi Industri, Yogyakarta: Liberty.

Gibson, J.L., J.M. Ivancevich, J.H. Donnelly, Jr., 1996, Organisasi, Perilaku, Struktur, Proses, Jakarta: Bina Rupa Aksara

Ilyas, Y., 2001, Kinerja, Teori, Penilaian dan Penelitian, Jakarta: Pusat Kajian Ekonomi Kesehatan Fakultas Kesehatan Masyarakat

Pasolong, Harbani, 2007. Teori Administrasi Publik. Bandung: Alfabeta.

Prawirosentana, Suyadi, 1999. Kebijakan Kinerja Karyawan Yogyakarta : BPFE

Purwodarminto, WJS., 1986. Kamus Umum Bahasa Indonesia. Jakarta: Balai Pustaka.

Robbins, Stephen, P. 2003. Organisasi Behavior. New Jersey : Prentice Hall.

Sarundajang, H. 2012. Pilkada Langsung, Problematika dan Prospek. Jakarta: Kata Hasta Pustaka.

Sedarmayanti. 2003. Good Governance (Kepemerintahan Yang Baik) Dalam RangkaOtonomi Daerah. Bandung: Mandar Maju.

Sugiyono, 2010. Metode Penelitian Kualitatif. Bandung: Alfabeta.

Tunggal, Hadi Setia. 2012. Undang-Undang Penyelenggaraan Pemilu. Jakarta: Harvarindo.
Wahidin, Samsul. 2008. Hukum Pemerintahan Darah, Mengawasi Pemilihan Umum Kepala Daerah. Malang: Pustaka Pelajar.

Wibowo, M. 2010. Manajemen Kinerja, Edisi Ketiga. Jakarta: PT. Raja Grafindo Persada

Widjaja, HAW. 2001. Otonomi Daerah dan Daerah Otonom. Jakarta: PT. Raja Grafindo Persada.

Wulandari,W., 2004. Kinerja Perawat Pada Unit BP Puskesmas di Kabupaten Lumajang, Tesis, Program Pascasarjana Universitas Airlangga Surabaya.

Yacub, Dahlan. 2001. Kamus Ilmiah Populer. Surabaya: Arkola.

http://seputar-indonesia.com/idisicetak/ 530060.html, di akses 28 september 2012.

http://palopopos.co.id/pvi=detail\&nid =53624.html, di akses 3 agustus 2012 .

http://kpu-lutrakab.go.id/indexphp?option. html, di akses 27 oktober 2012

http://kpu-lutra.g.id/inekxphp,panwasludan kpulutra-tindaklanjuti-pemilih-ganda? option.html, di akses 7 oktober 2012.

\section{Artikel}

Palopo Pos, Pemilih Ganda Rawan Picu Konflik, 04 September 2012,Masamba.

Palopo Pos, KPU temukan akar masalah DPT, 27 Juli 2012, Masamba.

\section{Dokumen-Dokumen}

Undang-Undang No. 32 Tahun 2004 Tentang Pemerintahan Daerah.

Undang-Undang Republik Indonesia Nomor 15 Tahun 2011 Tentang Penyelenggara Pemilihan Umum (Menggantikan UU 
No. 22/2007 tentang Penyelenggara Pemilihan Umum).

Keputusan Komisi Pemilihan Umum Provinsi Sulawesi Selatan Nomor 01/Pilgub/ Kpts-KPU-Prov-025/VI/2012 Tentang Tahapan, Program, dan Jadwal Penyelenggaraan Pemilihan Gubernur dan Wakil Gubernur Sulawesi Selatan Tahun 2013.
Rekapitulasi Jumlah Desa/Kelurahan Pemilih dan TPS per Kecamatan Kabupaten Luwu Utara Lingkup Sekretariat Komisi Pemilihan Umum Kabupaten Luwu Utara.

Lampiran Surat No:607/KPU-Prov-025/IX/ 2012, Perihal Permintaan Data Personil PPK, PPS dan KPPS Lingkup Sekretariat KPU Kabupaten Luwu Utara. 